\title{
Effects of Propolis on Selected Blood Indicators and Antioxidant Enzyme Activities in Broilers under Heat Stress
}

\author{
Pınar Tatlı Seven ${ }^{1}$, Seval Yılmaz ${ }^{2}$, Ismail Seven ${ }^{3}$, Ibrahim H. Cerc1 ${ }^{1}$, \\ Mehmet A. Azman ${ }^{1}$, Mehmet Yilmaz ${ }^{1}$ \\ ${ }^{1}$ University of Firat, Faculty of Veterinary Medicine, Department of Animal \\ Nutrition and Nutritional Diseases, Elazig, Turkey \\ ${ }^{2}$ University of Firat, Faculty of Veterinary Medicine, Department of Biochemistry, Elazig, Turkey \\ ${ }^{3}$ University of Firat, Vocation School of Sivrice, Department of Beekeping, Elazig, Turkey
}

Received November 13, 2007

Accepted December 15, 2008

\begin{abstract}
In this study, we investigated the antioxidant activity of ethanol extracts of propolis (EEP) and vitamin $\mathrm{C}$ on biochemical indicators and antioxidant enzyme activities of broilers exposed to heat stress (at $34^{\circ} \mathrm{C}$ ). The experimental groups were as follows: group I (positive control) and group II (control) were fed a basal diet, group III (vitamin C) was fed a basal diet supplemented with $250 \mathrm{mg}$ vitamin $\mathrm{C}$ as ascorbic acid/kg, group IV (EEP-0.5) was fed a basal diet supplemented with $0.5 \mathrm{~g} \mathrm{EEP} / \mathrm{kg}$, group $\mathrm{V}$ (EEP-1) was fed a basal diet supplemented with $1 \mathrm{~g} \mathrm{EEP} / \mathrm{kg}$, group VI (EEP-3) was fed a basal diet supplemented with $3 \mathrm{~g} \mathrm{EEP} / \mathrm{kg}$. Plasma superoxide dismutase levels of positive control, control, vitamin C, EEP-0.5, EEP-1 and EEP-3 groups were found as $0.34,1.23,0.50,0.90,0.30$ and $0.41 \mu \mathrm{kat} / \mathrm{ml}$, respectively $(p<0.01)$. Aspartate transaminase (except for EEP-0.5 and EEP-1 groups) and alkaline phosphatase in the control group were significantly higher than those of positive control, vitamin-C and EEP-3 groups. Malondialdehyde level in plasma, liver and muscle tissues of control group were found significantly $(p<0.05)$ higher than those of positive control and EEP3 groups. Catalase activities of blood, liver, kidney and heart were the highest in the control group. Reduced glutathione activities of plasma and liver of all groups were not significantly different from each other, whereas those of muscle, kidney and heart were significantly higher in the control group. Significantly lower levels of glutathione peroxidase were found in blood, liver and kidney tissues of the control group $(p<0.05)$, whereas those of muscle and heart were similar in all groups. The results of the present study suggest that EEP and specially EEP at the supplemented dose of $3 \mathrm{mg} / \mathrm{kg}$ diet might be considered to prevent oxidative stress in the broilers exposed to heat stress.
\end{abstract}

Propolis, antioxidant enzymes, blood, heat stress, broilers

Ambient temperature is an important factor in poultry breeding. Temperature suitable for poultry ranges between $16-25{ }^{\circ} \mathrm{C}$ (Filizciler et al. 2002; Cerci et al. 2003). Heat stress reduces feed intake, body weight gain and feed conversion (Tatli Seven 2008). At the same time, heat stress increases lipid peroxidation as a consequence of increased free radical generation. It can enhance the formation of reactive oxygen species (ROS) and induce oxidative stress in cells. Oxidative damage may be minimized by antioxidant defence mechanisms that protect the cell against cellular oxidants and repair systems that prevent the accumulation of oxidatively damaged molecules. Antioxidant enzymes catalase (CAT), superoxide dismutase (SOD), glutathione peroxidase (GSH-Px) play a vital role in protecting cellular damage from harmful effects of ROS (Altan et al. 2003). The increase in lipid peroxidation decreases antioxidants such as vitamin $\mathrm{C}$ and vitamin $\mathrm{E}$ in tissues (Tatli Seven 2008).

Vitamin $\mathrm{C}$ has been supplemented to diets of poultry reared under stress. In addition, several works revealed a beneficial effect of ascorbic acid supplementation on the growth rate in stressed-laying hens and broilers (Bains 1996; Tatli Seven and Seven 2008). Vitamin $\mathrm{C}$ supplementation leads to strengthening the antioxidative defence and a consequent decreasing of oxidative stress (Tatli Seven 2008).

Address for correspondence:

Assoc. Prof. Dr. Pinar Tatli Seven

University of Firat, Faculty of Veterinary Medicine,

Dept. of Animal Nutrition and Nutritional Diseases

23119, Elazig, Turkey
Phone: +90 $4242370000 / 3934$

Fax: +904242388173

E-mail: pintatli@hotmail.com

http://www.vfu.cz/acta-vet/actavet.htm 
Propolis is an adhesive, dark yellow to brown coloured balsam that smells like resin. It is collected from the buds, leaves and similar parts of trees and plants like pine, oak, eucalyptus, poplar, chestnut, etc. by bees and mixed with their wax. Propolis supplementation is used in poultry diets (Tatli Seven 2008; Tatli Seven and Seven 2008). The anti-oxidative, cytostatic, anti-mutagenic and immunomodulatory properties of propolis are based on its rich, flavonoid, phenolic acid and terpenoid contents (Kimoto et al. 1999; Prytzyk et al. 2003; Wang et al. 2004). It is known that flavonoids show antioxidant characteristics to the oxidants in the cell membrane like ascorbate (Havsteen 2002). Another compound in the structure of propolis, caffeic acid phenethyl ester, blocks the production of reactive oxygen types (Hosnuter et al. 2004).

Although it is known that propolis is effective similarly to vitamin $\mathrm{C}$ in cell membrane in oxidative stress conditions, the current study aimed to assess whether propolis prevents the negative effects caused by heat stress on biochemical indicators and antioxidant enzyme activities that are also found with vitamin $\mathrm{C}$ supplementation. The study was designed to determine the effects of propolis and vitamin $\mathrm{C}$ on biochemical indicators and antioxidant enzyme activities, and to compare the effects on these indicators of vitamin $\mathrm{C}$ and propolis that have antioxidant effects in broilers under heat stress.

\section{Materials and Methods}

Animals and diets

The experiment was in accordance with animal welfare, and was conducted under the protocols of the Veterinary Faculty in Elazig, Turkey. In this study, a total of 660 one-day-old broiler chicks (Ross 308) were used. The chicks were randomly divided into 1 positive control, 1 control and 4 treatment groups. For the positive control group, sixty broilers were randomly selected and separated to three replicate groups, each containing 20 animals. The temperature was maintained at $34{ }^{\circ} \mathrm{C}$ for the first 2 days, and then decreased gradually to $21{ }^{\circ} \mathrm{C}$ (thermoneutral chamber, average $24^{\circ} \mathrm{C}$ ). Six-hundred broilers were randomly selected for the heat stress chamber. Three replicate groups of 40 chicks were assigned to each of the control and 4 treatment groups. They were exposed to high temperature $\left(34^{\circ} \mathrm{C}\right)$ for 41 days. Corn and soybean meal-based feeds were formulated according

Table 1. Composition of the experimental diets, \%

\begin{tabular}{|l|c|c|}
\hline Ingredients & Starter & Finishing \\
\hline Corn & 56.00 & 60.81 \\
\hline Soybean meal & 31.70 & 25.25 \\
\hline Fish meal & 6.50 & 5.60 \\
\hline Soybean oil & 3.50 & 4.80 \\
\hline Limestone & 1.00 & 0.95 \\
\hline Dicalcium phosphate & 0.20 & 1.60 \\
\hline L-Lysine hydrochloride & 0.20 & 0.04 \\
\hline Vitamin-mineral premix ${ }^{1}$ & 0.35 & 0.50 \\
\hline DL- Methionin & 0.30 & 0.20 \\
\hline Sodium chloride & 0.25 & 0.25 \\
\hline Calculated nutrient content & \multicolumn{2}{|l|}{} \\
\hline ME, MJ $/ \mathrm{kg}^{2}$ & 12.95 & 13.33 \\
\hline CP, $\%{ }^{3}$ & 23.20 & 21.70 \\
\hline Calcium, $\%{ }^{2}$ & 1.00 & 1.02 \\
\hline Total phosphorus, $\%{ }^{2}$ & 0.56 & 0.59 \\
\hline
\end{tabular}

${ }^{1}$ Vitamin and mineral premix provided per kilogram of diet: vitamin A, $12.000 \mathrm{IU}$; cholecalciferol $1.500 \mathrm{IU}$; vitamin E, $30 \mathrm{mg}$; vitamin $\mathrm{K} 3,5 \mathrm{mg}$; vitamin B1, $3 \mathrm{mg}$; vitamin B2, $6 \mathrm{mg}$; vitamin B6, $5 \mathrm{mg}$; vitamin B12, $30 \mu \mathrm{g}$; Ca-D- panthotenate, $10 \mathrm{mg}$; folic acid, $0.75 \mathrm{mg}$; D-biotin, $0.08 \mathrm{mg}$; Mn, $80 \mathrm{mg}$; Zn, $60 \mathrm{mg} ; \mathrm{Fe}, 40$ $\mathrm{mg}$; $\mathrm{Cu}, 5 \mathrm{mg}$; Se, $0.15 \mathrm{mg}$; Co, $0.1 \mathrm{mg} ; \mathrm{I}, 0.4 \mathrm{mg}$

${ }^{2}$ Based on NRC (1994) feed composition tables

${ }^{3}$ Analysed (AOAC, 1990) to the requirements suggested by the NRC (1994). Diets were formulated as starter (until 28 d) and finisher diets (between 28 and 41 d) (Table 1). The experimental groups were as follows; group I (positive control) and group II (control) were fed a basal diet, group III (vitamin C) was fed a basal diet supplemented with $250 \mathrm{mg} / \mathrm{kg}$ vitamin $\mathrm{C}$ as ascorbic acid, group IV (EEP0.5 ) was fed a basal diet supplemented with $0.5 \mathrm{~g} / \mathrm{kg}$ EEP, group V (EEP-1) was fed a basal diet supplemented with $1 \mathrm{~g} /$ kg EEP, group VI (EEP-3) was fed a basal diet supplemented with $3 \mathrm{~g} / \mathrm{kg}$ EEP. Small amounts of the basal diet were first mixed with the respective amounts of vitamin $\mathrm{C}$ and propolis as a small batch and then with a larger amount of the basal diet, until the total amount of the respective diets were homogeneously mixed. The birds were fed a starter diet until $21 \mathrm{~d}$ of age, followed by a finishing diet until $41 \mathrm{~d}$ of age. The diets and fresh water were offered ad libitum. On day 41, 18 birds (9 males and 9 females from each group) were killed by cervical dislocation. Blood samples were collected from the brachial vein of 18 birds from each group on day 41. Plasma, liver, muscle, kidney and heart samples were taken immediately. 
Table 2. Chemical composition assessed by GC-MS of EEPa

\begin{tabular}{|c|c|c|}
\hline RT (min) & Contents & $\mathrm{TIC} \%$ \\
\hline & Flavonoids & \\
\hline 52.49 & Chrysin & 5.33 \\
\hline 53.67 & Acacetin & 3.02 \\
\hline \multirow[t]{2}{*}{51.66} & Naringenin & 2.67 \\
\hline & Aliphatic acids & \\
\hline 55.49 & Decanoic acid & 0.28 \\
\hline 46.93 & Octadecanoic acid & 0.39 \\
\hline 21.00 & Tetradecanoic acid & 0.40 \\
\hline 51.22 & Undecanoic acid & 0.79 \\
\hline \multirow[t]{2}{*}{7.18} & Butanedioic acid & 0.77 \\
\hline & Aromatic acids & \\
\hline 26.93 & Ferulic acid & 0.43 \\
\hline 24.80 & Cinnamic acid & 0.41 \\
\hline \multirow[t]{2}{*}{31.20} & Palmitoleic acid & 0.51 \\
\hline & Esters & \\
\hline 34.92 & 4,3 acetyloxycaffeate & 0.52 \\
\hline \multirow[t]{2}{*}{36.33} & Caffeic acid TMS ester & 0.39 \\
\hline & Alcohol, terpen ve quinonee & \\
\hline 11.43 & 1-propen-1 thiol & 4.51 \\
\hline 7.18 & 1-cyklohexene-1-methanol & 4.64 \\
\hline 28.93 & Farnesol & 20.64 \\
\hline 14.97 & Limonene dioxide & 0.78 \\
\hline \multirow[t]{2}{*}{6.87} & Glycerole & 1.04 \\
\hline & Others & \\
\hline 11.43 & 1H-cyclopentafuran & 3.17 \\
\hline 53.43 & 3- hexane & 1.61 \\
\hline 56.46 & Heptane & 0.02 \\
\hline 42.17 & 1,3 bis 5 propylbenzene & 0.55 \\
\hline
\end{tabular}

RT: Retention time

a: The ion current generated depends on the characteristics of the compound concerned and it is not a true quantitation
Sample collection and biochemical assays

Propolis samples were collected from the Elazig Province (East Anatolia). Handcollected propolis samples were kept desiccated in dark until the processing. Collected propolis was extracted for a week with $100 \mathrm{ml}$ of $70 \%$ ethanol at room temperature to obtain the extract. After filtration, the extract was evaporated using a vacuum evaporator at $50{ }^{\circ} \mathrm{C}$ and then used in the experiment. Gas chromatography-mass spectrometry was carried out to detect main components of propolis by the Agillent GC 6890 gas chromatograph coupled to the Agillent MSD 5973 mass detector under electron impact ionization. The chromatographic column for the analysis was Zebron (ZB1) methyl polysiloxane column $(30 \mathrm{~m} \mathrm{~L} \times$ $0.25 \mathrm{~mm} 10 \times 0.25 \mathrm{~mm} \mathrm{df}$ ). The carrier gas used was helium at a flow rate of $10 \mathrm{ml} /$ min. The propolis sample was analyzed with the column held initially at $100{ }^{\circ} \mathrm{C}$ for $5 \mathrm{~min}$ and then increased to $150{ }^{\circ} \mathrm{C}$ and then kept at $150{ }^{\circ} \mathrm{C}$ for $2 \mathrm{~min}$. Finally, the temperature was increased to $280{ }^{\circ} \mathrm{C}$ with a $2{ }^{\circ} \mathrm{C} / \mathrm{min}$ heating ramp, and the temperature was kept at $280{ }^{\circ} \mathrm{C}$ gradually for $60 \mathrm{~min}$ for sample. The injection was performed in a split mode at $250{ }^{\circ} \mathrm{C}$, and the peaks were identified by computer searches in commercial reference libraries. The main components of propolis samples were determined by considering their areas as percentage of the total ion current. The main compounds of the propolis sample were identified and are listed in Table 2.

The broilers in control and treatment groups were kept under the same environmental conditions. The crude protein of the diet was determined according to AOAC (1990). Blood samples were taken into tubes containing anticoagulant (2\% sodium oxalate). The samples were centrifuged at $200 \mathrm{~g}$ for $5 \mathrm{~min}$ at $+4{ }^{\circ} \mathrm{C}$; then the plasma was removed immediately and stored at $-20{ }^{\circ} \mathrm{C}$ until analyzed. Plasma biochemical indicators were measured using an auto analyzer (Olympus AU 600, Japan). Tissue specimens (liver, muscle, kidney, heart) were rinsed with saline to remove the blood. The homogenization of tissues was carried out in a Teflon-glass homogenizer with a buffer containing $1.15 \% \mathrm{KCl}$ to obtain $1: 10(\mathrm{w} / \mathrm{v})$ whole homogenate. The homogenates were centrifuged at $18.000 \mathrm{~g}\left(+4^{\circ} \mathrm{C}\right)$ for $15 \mathrm{~min}$ to determine malondialdehyde (MDA), reduced glutathione (GSH) concentrations, CAT and GSH-Px activities.

The SOD activity was measured using the RANSOD kit. The role of SOD is to accelerate the dismutation of the toxic superoxide radical, produced during oxidative energy processes, to hydrogen peroxide and molecular oxygen. Plasma MDA concentration, the end product of lipid peroxidation, was measured according to the method of Satoh (1978). MDA contents of tissue homogenates were assayed spectrophotometrically according to the method of Ohkawa et al. (1979). MDA concentrations in plasma and tissue were expressed as $\mathrm{nmol} / \mathrm{ml}$ and $\mathrm{nmol} / \mathrm{mg}$ protein tissue, respectively. The CAT activity was estimated by measuring the breakdown of $\mathrm{H}_{2} \mathrm{O}_{2}$ at $240 \mathrm{~nm}$ according to the method of Aebi (1984) and expressed as k/g protein in tissues. Tissue GSH concentration was measured by an assay using the dithionitrobenzoic acid recycling method described by Ellman (1959) and was expressed as nmol/ml. Tissue protein contents were determined by the method of Lowry (1951). The GSH-Px activity was determined using the method of Beutler (1975), which records the disappearance of NADPH at $340 \mathrm{~nm}$. The action of GSH-Px is to reduce $\mathrm{H}_{2} \mathrm{O}_{2}$, with coupled oxidation of NADPH. The procedure of analysis performed was based on the oxidation of GSH by GSH-Px coupled to the disappearance of NADPH by glutathione reductase measured at $37{ }^{\circ} \mathrm{C}$ and $340 \mathrm{~nm}$ and were expressed as U/g protein. 


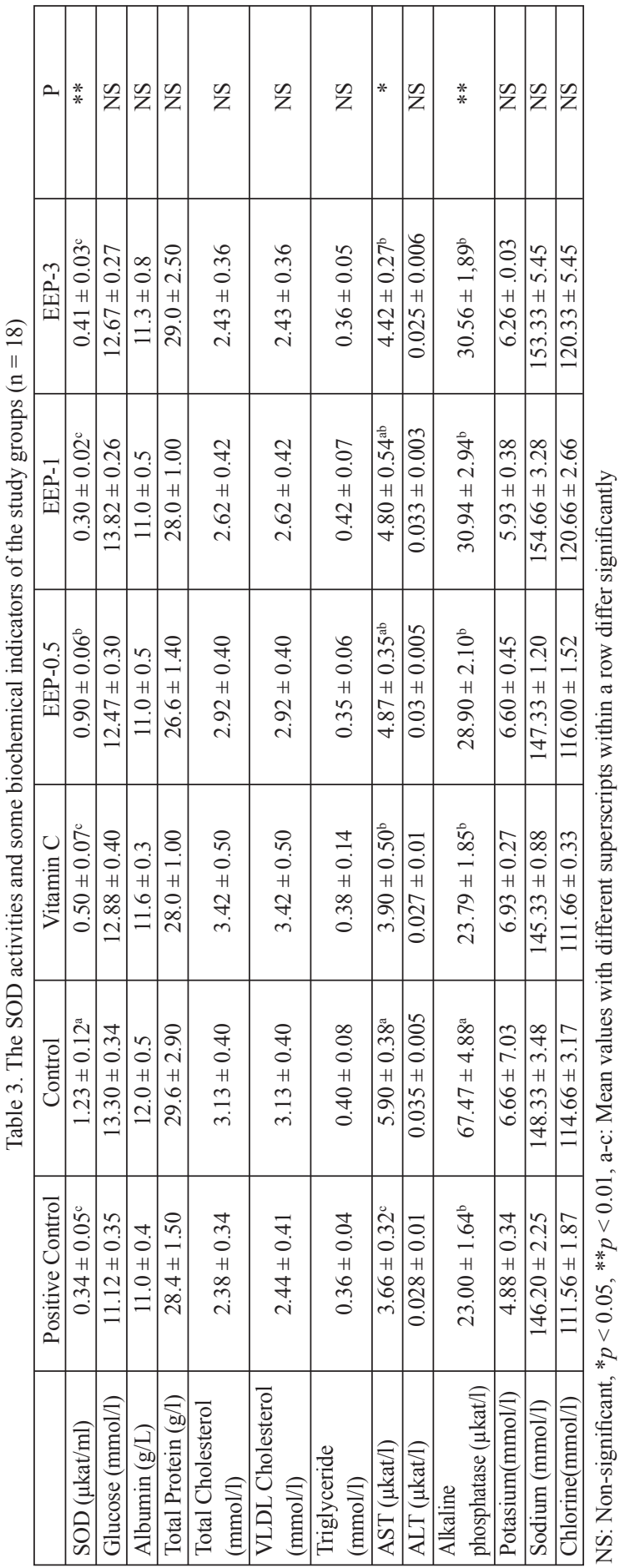

Statistical analysis

All values were presented as means \pm SEM. Differences between group means were calculated by one-way analysis of variance (ANOVA) and post-hoc Duncan test used by SPSS/PC computer program (SPSS 1999). Results were considered significant at $p<0.05$.

\section{Results}

Plasma SOD levels of positive control, control, vitamin C, EEP0.5 , EEP-1 and EEP-3 groups were found as $0.34,1.23,0.50,0.90$, 0.30 and $0.41 \mu \mathrm{kat} / \mathrm{ml}$, respectively $(p<0.01)$ (Table 3$)$. It was obvious that plasma SOD activity was affected by heat exposure. Plasma SOD activity was significantly increased in the control group compared to positive control and other supplement groups $(p<0.01)$ (Table 3). The values of plasma glucose, albumin, total protein, total cholesterol, VLDL, triglyceride, aspartate transaminase, alanine transaminase, alkaline phosphatase, potassium, sodium and chlorine of groups were presented in Table 3. The glucose, albumin, total protein, total cholesterol, VLDL cholesterol, triglyceride, alanine transaminase, potasium, sodium, chlorine in blood were not significantly influenced by heat exposure (Table 3). Aspartate transaminase (AST) (except for EEP-0.5 and EEP-1 groups) and alkaline phosphatase (ALP) in the control group were significantly higher than those of positive control, vitamin $\mathrm{C}$ and EEP-3 groups $(p<0.01)$.

MDA level in plasma, liver and muscle tissues of control group were found significantly higher than those of positive control and EEP-3 groups. MDA levels of kidney and heart were similar in all groups (Table 4). The MDA activity was significantly increased in plasma, 


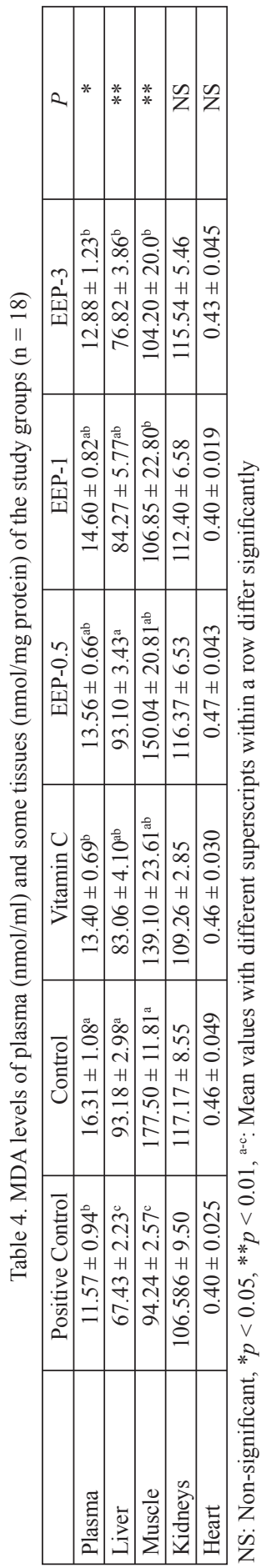

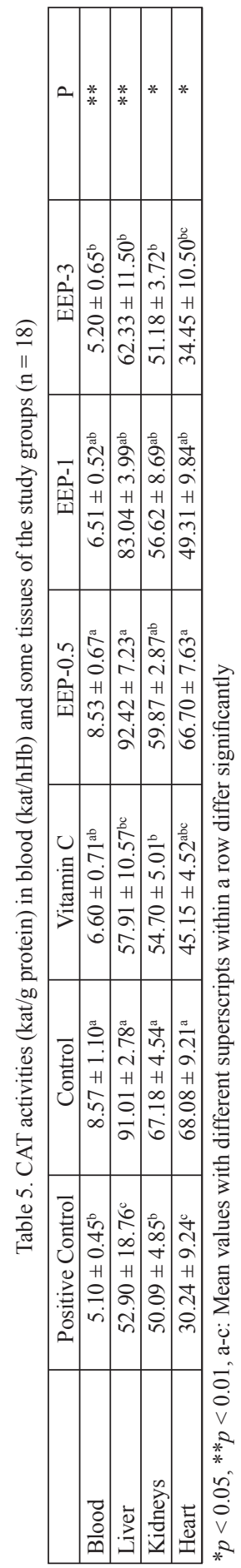

liver and muscle by heat exposure.

CAT activities of blood, kidney and heart were the highest in the control group. The CAT activity of EEP-3 group was found significantly lower than that of the control group (Table 5). Its CAT activities for all tissues were found nearest to the positive control group exposed to normal temperature.

GSH activities of plasma of all the groups were not significantly different from each other, whereas those of muscle, kidney and heart were significantly higher in the control group (Table 6). Liver GSH activity was obviously affected by heat exposure, but EEP and vitamin $\mathrm{C}$ supplementations were not sufficient to decrease its activity. Liver GSH activity of the positive control group was the least when compared to the other groups.

Significantly lower levels of GSH-Px were found in blood, liver and kidney tissues of the control group $(p<0.05)$, whereas those of muscle and heart were similar in supplement groups. GSH-Px activities of positive control and EEP-3 groups were found the highest among the groups (Table 7).

\section{Discussion}

The effects of supplementations of reference antioxidant vitamin $\mathrm{C}$ and EEP affected antioxidant on someblood indicators on level of MDA, and the activities of SOD, CAT, GSH, and GSH-Px in broilers exposed to heat were determined.

We found that the glucose, albumin, total protein, total cholesterol, VLDL cholesterol, triglyceride, alanine transaminase, potassium, sodium, chlorine in blood were not influenced by the vitamin $\mathrm{C}$ and EEP treatments. Biavatti et al. (2003) reported that propolis had no influence on biochemical indicators including glucose, creatinine, cholesterol, triglyceride, AST and ALT. However, different studies indicated that propolis aleviated too high blood lipid, high total cholesterol and arteriosclerosis (Akgul et al. 1997; Burdock 1998; Castaldo and Capasso 2002). In the present study, it was found that AST and ALP levels were significantly decreased in positive control, vitamin $\mathrm{C}$ and EEP 


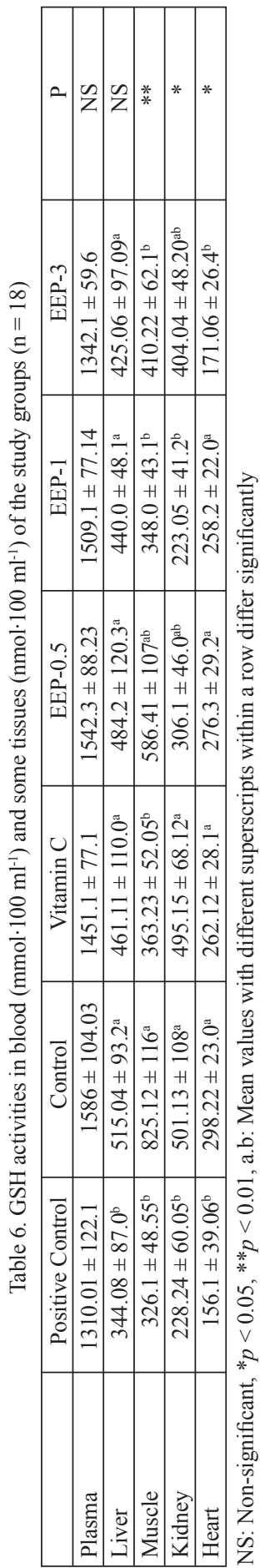

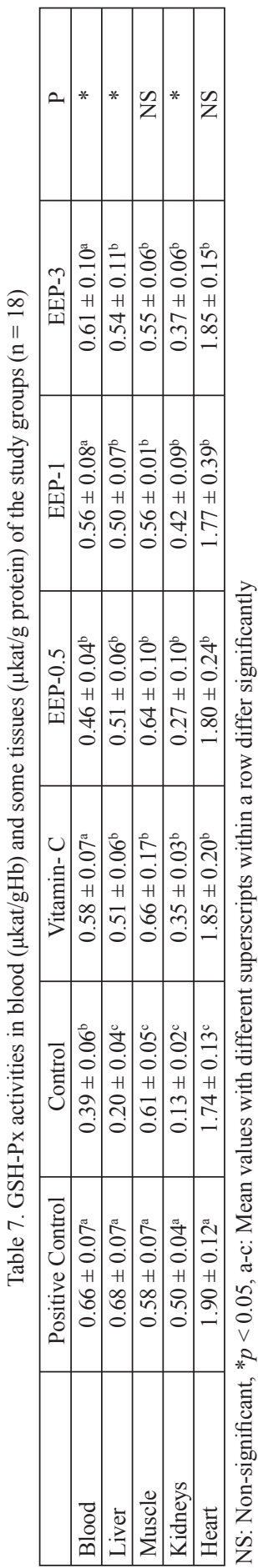

groups compared to those in the control group. Zaidi et al. (2005) reported that the AST activity in blood significantly increased under stress. The AST findings may be an evidence for vitamin $\mathrm{C}$ and EEP decreasing the stress of broilers, in consistency with the previous study (Zaidi et al. 2005; Yousef et al. 2006). Once again, Kolankaya et al. (2002) reported that the plasma AST level was decreased by supplementary propolis. The results of the present study were in agreement with those reported by Kolankaya et al. (2002). Similarly, the ALP activity in blood was significantly increased in the control group compared to the other groups $(p<0.01)$. This can be explained by the heat stress. Likewise, it is noted that in studies related to stress, oxidative damage increased the ALP activity (Kaur et al. 2006; Manna et al. 2006; Yousef et al. 2006).

Heat stress is an important stressor resulting in the reduced welfare of birds. Heat stress increased lipid peroxidation as a consequence of increased free radical generation. The rise of lipid peroxidation increases the MDA level in blood and tissues (Okutan et al. 2005; Ates et al. 2006). In this study, it was found that plasma, liver and muscle MDA levels were significantly decreased in positive control, vitamin C and EEP-3 groups compared to those in the control. It may be considered that dietary vitamin $\mathrm{C}$ and a high dose of EEP (EEP-3 group) decreased lipid peroxidation. Besides, $3 \mathrm{~g} / \mathrm{kg}$ dietary EEP was found more effective than vitamin $\mathrm{C}$, on especially liver and muscle MDA levels. Likewise, Okonenko et al. (1988) reported that propolis had more pronounced antioxidant action compared to that of vitamin $\mathrm{E}$ that has a similar activity to vitamin $\mathrm{C}$.

Living organisms are able to adapt to oxidative stress by inducing the synthesis of antioxidant enzymes and damage removal/repair enzymes (Davies 1995). Antioxidant enzyme activities such as SOD and CAT in lipid peroxidation may 
sometimes decrease (Wohaieb and Godin 1987; Ozkaya et al. 2002) or increase (Huang et al. 1999; Aliciguzel et al. 2003). In the present study, the increase of antioxidant enzyme activities such as SOD, CAT and GSH may be considered as a protective mechanism against heat-induced free radical production and lipid peroxidation. Exposing birds to heat stress resulted in a significant increase in SOD and CAT (Altan et al. 2003). Moreover, significant differences between enzymes were obtained in antioxidant enzyme responses to heat treatment. A similar response has been reported in many human diseases, in which MDA concentrations increased concomitantly with an increase in antioxidant enzyme activities. McArdle and Jackson (2000) have also demonstrated a significant increase in free radical production together with an increase in the expression of antioxidant enzymes during a period of non-damaging exercise. These increases in antioxidant enzyme activities have been considered as a protective response against oxidative stress (Altan et al. 2003). In a previous study, Okutan et al. (2005) investigated the effects of caffeic acid phenethyl ester (CAPE), which is a component of propolis, on lipid peroxidation and antioxidant enzymes in a diabetic rat heart. They found that in the untreated diabetic group, the SOD activities and CAT levels were significantly decreased, while the GSH-Px activity was increased in the CAPE-treated diabetic rats compared to those observed in untreated diabetic rats ( $p<0.0001$ and $p=0.016$, respectively). The findings reported by Okutan et al. (2005) were in agreement with our results. The GSH-Px activities of blood, liver and kidney in the control group were significantly reduced, while SOD, CAT and GSH activities were increased in blood and some tissues in the control group. This may be explained by the activity of GSH-Px in inhibition of increased free radicals in tissues (Nakazawa et al. 1996). In the present study, levels of MDA, antioxidant enzymes (SOD and GSH-Px) and GSH of blood and some organs were found similar in the groups. It can be speculated that there was no correlation of antioxidant enzyme activities between tissues (Irmak et al. 2003). Similarly, Okutan et al. (2005) reported that there is no consensus in the level of antioxidant enzymes of many organs in diabetic rats.

It can be concluded that heat stress in broilers increases oxidative stress in blood and tissues. Generally, it was found nearest to values of vitamin C and EEP-3 groups compared with those of the positive control group. EEP decreased lipid peroxidation and regulated antioxidant enzyme activities in the broilers exposed to heat stress. The protective role of EEP might be related to its antioxidant effect. The results of this study suggest that EEP and especially EEP at the supplemented dose of $3 \mathrm{mg} / \mathrm{kg}$ diet might be considered in the prevention of oxidative stress in broilers exposed to heat stress.

\section{Vliv propolisu na vybrané biochemické ukazatele stanovované v krvi, a aktivitu antioxidačních enzymů brojlerových kuřat vystavených tepelnému stresu}

V této studii byla sledován vliv antioxidační aktivity etanolových extraktů propolisu (EEP) a vitamínu $\mathrm{C}$ na biochemické indikátory a aktivitu antioxidačních enzymů u brojlerů vystavených tepelnému stresu $\left(34^{\circ} \mathrm{C}\right)$. Experimentální skupiny byly následující: skupina I (pozitivní kontrola) a skupina II (negativní kontrola) krmená základní dietou, skupina III (vitamin C) krmená základní dietou doplněnou o $250 \mathrm{mg}$ vitaminu C formou kyseliny askorbové/kg, skupina IV (EEP-0.5) krmená základní dietou s prŕ́davkem $0.5 \mathrm{~g} \mathrm{EEP} / \mathrm{kg}$, skupina V (EEP-1) krmená základní dietou s přídavkem $1 \mathrm{~g}$ EEP/kg, skupina VI (EEP-3) krmená základní dietou doplněnou o $3 \mathrm{~g}$ EEP/kg. Aktivita superoxiddismutázy v krevní plazmě pozitivních kontrol, negativních kontrol, skupiny III, IV, V a VI byly naměřeny takto: $0,34,1,23,0,50,0,90,0,30$ a $0,41 \mu \mathrm{kat} / \mathrm{ml} \mathrm{s}$ průkazností $(p<0.01)$. Aktivita aspartátaminotransferázy (AST) u všech skupin kromě IV a V, a aktivita alkalické fosfatázy (ALP) v negativní kontrole byla signifikantně vyšší než u pozitivních kontrol, skupině III a VI. Obsah malondialdehydu v krevní plazmě, jaterní a svalové tkáni u kuřat kontrolní skupiny (skupina II) byla signifikantně $(p<0.05)$ zvýšená ve srovnání s pozitivní kontro- 
lou a skupinou VI. Nejvyšší hodnoty enzymatické aktivity katalázy v krvi, jaterní tkáni, v ledvinách a srdci byly naměřeny v negativní kontrole. Redukovaný glutathion v krevní plazmě a v jaterní tkáni kuřat všech experimentálních skupin nebyl významně změněný, avšak signifikantně vyšší hladiny GSH byly zjištěny ve svalech, ledvinách a myokardu u negativních kontrol. Průkazně nižší aktivita glutathionperoxidázy byla zjišsěna v krvi, játrech a ledvinách u brojlerů kontrolní skupiny II $(p<0.05)$, zatímco její aktivita v kosterní svalovině a myokardu byla srovnatelná ve všech skupinách. $Z$ výsledků této studiě vyplývá, že suplementace krmiva brojlerů výtažky z propolisu, konkrétně v dávce $3 \mathrm{mg} / \mathrm{kg}$ krmiva, hraje pozitivní úlohu v prevenci oxidačního stresu brojlerů vystavených účinkům tepelného stresu.

\section{Acknowledgement}

This study was funded by TUBITAK.

\section{References}

AOAC 1990: Official methods of analysis of the Association of Official Analytical Chemists. 15 ${ }^{\text {th }}$ ed. Washington, DC, Association of official analytical chemists

Aebi H 1984: Catalase in vitro. In: WILLIAM BJ (Ed.): Methods in enzymology. Academic Press, New York, pp. 121-126

Akgul E, Ilhan N, Halifeoglu IL Var A 1997: Plasma lipid peroxide levels and antioxidant enzyme activities in type II diabetics: Relationship with diabetic microagiopatic complications. Atherosclerosis 130 (Suppl.): 9

Aliciguzel Y, Ozen I, Aslan M, Karayalcin U 2003: Activities of xanthine oxidoreductase and antioxidant enzymes in different tissues of diabetic rats. J Lab Clin Med 142: 172-177

Altan O, Pabuccuoglu A, Altan A, Konyalioglu S, Bayraktar H 2003: Effect of heat stress on oxidative stress, lipid peroxidation and some stress parameters in broilers. Br Poult Sci 44: 545-550

Ates B, Dogru MI, Gul M, Erdogan A, Dogru Ak, Yilmaz I, Yurekli M, Esrefoglu M 2006: Protective role of caffeic acid phenethyl ester in the liver of rats exposed to cold stress. Fundam Clin Pharmacol 20: 283-289

Bains BS 1996: The role of vitamin C in stress management. Missset World Poultry 12: 38-41

Beutler E 1975: Red cell metabolism. In: Beutler E (Ed.): A manual of biochemical methods. Grune and Stratton, New York, pp. 67-69

Biavatti MW, Bellaver MH, Volpato L, Costa C, Bellaver C 2003: Preliminary studies of alternative feed additives for broilers: Alternanthera brasiliana extract, propolis extract and linseed oil. Rev Bras Cienc Avic 5: 147-151

Burdock GA 1998: Review of the biological properties and toxicity of bee propolis. Food Chem Toxicol 36: 347-363

Castaldo S, Capasso F 2002: Propolis an old remedy used in modern medicine. Fitoterapia 73: 1-6

Cerci IH, Tatli Seven P, Azman MA, Birben N 2003: The effect of restricted feed on feed intake, egg production and feed conversion in pullets. Indian Vet J 80: 1153-1157

Davies KJ 1995: Oxidative stress: the paradox of aerobic life. Biochem Soc Symp 61: 1-31

Ellman GL 1959: Tissue sulfhydryl groups. Arch Biochem Biophys 82: 70-77

Filızciler M, Cerc1 IH, Tatlı P 2002: Effects of night feeding on SPF (specific pathogen free) white egg layers under heat stress (in Turkish). Turk J Vet Anim Sci 26: 439-446

Havsteen BH 2002: The biochemistry and medical significance of the flavonoids. Pharmacol Ther 96: 67-202

Hosnuter M, Gurel A, Babuccu O, Armutcu F, Karg1 E, Isıkdemır A 2004: The effect of CAPE on lipid peroxidation and nitric oxide levels in the plasma of rats following thermal injury. Burns 30: 121-125

Huang WC, Juang SW, Liu IM, Chi TC, Cheng JT 1999: Changes of superoxide dismutase gene expression and activity in the brain of streptozotocin-induced diabetic rats. Neurosci Lett 5: 25-28

Irmak MK, Fadillioglu E, Sogut S, Erdogan H, Gulec M, Ozer M, Yagmurca M, Gozukara ME 2003: Effects of caffeic acid phenethyl ester and alpha-tocopherol on reperfusion injury in rat brain. Cell Biochem Funct 21: 283-289

Kaur G, Tirkey N, Bharrhan S, Chanana V, Rishi P, Chopra K 2006: Inhibition of oxidative stress and cytokine activity by curcumin in amelioration of endotoxin-induced experimental hepatoxicity in rodents. Clin Exp Immunol 145: 313-321

Kimoto N, Hirose M, Kawabe M, Satoh T, Miyataka H, Shirai T 1999: Post-initiation effects of a super critical extract of propolis in a rat two-stage carcinogenesis model in female F344 rats. Cancer Lett 147: 221-227

Kolankaya D, Selmanoglu G, Sorkun K, Salih B 2002: Protective effects of Turkish propolis on alcohol-induced serum lipid changes and liver injury in male rats. Food Chem 78: 213-217

Lowry OH, Rosebrough NJ, Farr AL, Randall RJ 1951: Protein measurements with the Folin phenol reagent. J Biol Chem 193: 265-275 
Manna P, Sinha M, Sil PC 2006: Aqueous extract of Terminalia arjuna prevents carbon tetrachloride induced hepatic and renal disorders. BMC Complement Altern Med 6: 33

McArdle A, Jackson MJ 2000: Exercise, oxidative stress and ageing. J Anat 197: 539-541

Nakazawa H, Genka C, Fujishima M 1996: Pathological aspect of active oxygens/free radicals. Jpn J Physiol 46: 15-32

NRC 1994: Nutrient Requirements of Poultry. $9^{\text {th }}$ rev ed. National Academy Press, Washington DC, 176 p.

Ohkawa H, Ohishi N, Yagi K 1979: Assay for lipid peroxides in animal tissues by thiobarbituric acid reaction. Anal Biochem 95: 351-358

Okonenko LB, Aidarkhanov BB, Rakhmetova AA, Zhakisheva SSH, Iksymbaeva ZHS 1988: Vitamin E and propolis as antioxidants after excessive administration of polyunsaturated fatty acids. Vopr Pitan 4: 68-70

Okutan H, Ozcelik N, Yilmaz HR, Uz E 2005: Effects of caffeic acid phenethyl ester on lipid peroxidation and antioxidant enzymes in diabetic rat heart. Clin Biochem 38: 191-196

Ozkaya YG, Agar A, Yargicoglu P, Hacioglu G, Bilmen-Sarıkcioglu S, Ozen I, Alıciguzel Y 2002: The effect of exercise on brain antioxidant status of diabetic rats. Diabetes Metab 28: 377-384

Prytzyk E, Dantas AP, Salomao K, Pereira AS, Bankova VS, De Castro SL, Neto FR 2003: Flavonoids and trypanocidal activity of Bulgarian propolis. J Ethnopharmacol 88: 189-193

Satoh K 1978: Serum lipid peroxide in cerebrovascular disorders determined by a new colorimetric method. Clin Chim Acta 90: 37-43

Seven A, Tasan E, Inci F, Hatemi H, Burcak G 1998: Biochemical evaluation of oxidative stress in propylthiouracil treated hyperthyroid patients. Effects of vitamin C supplementation. Clin Chem Lab Med 36: 767-770

SPSS 1999: Spss for Windows, 10.1 Spss Inc.

Tatl seven P 2008: The effects of dietary Turkish propolis and vitamin C on performance, digestibility, egg production and egg quality in laying hens under different environmental temperatures. Asian Australas J Anim Sci 21: 1164-1170

Tatlı Seven P, Seven I 2008: Effect of dietary Turkish propolis as alternative to antibiotic on performance and digestibility in broilers exposed to heat. J Appl Anim Res 34: 193-196

Wang BJ, Lien YH, Yu ZR 2004: Supercritical fluid extractive fractionation: study of the antioxidant activities of propolis. Food Chem 86: 237-243

Wohaieb SA, Godin DV 1987: Alterations in free radical tissue-defence mechanisms in streptozocin-induced diabetes in rat: effect of insulin treatment. Diabetes 36: 1014-1018

Yousef MI, Awad TI, Mohamed EH 2006: Deltamethrin-induced oxidative damage and biochemical alterations in rat and its attenuation by vitamin E. Toxicology 227: 240-247

Zaidi SM, Al-Qirim TM, Banu N 2005: Effects of antioxidant vitamins on glutathione depletion and lipid peroxidation induced by restraint stress in the rat liver. Drugs R D 6: 157-165 
